\title{
Penilaian Early Language Milestone Scale 2 [EIm Scale2] Pada Anak dengan Keterlambatan Bicara
}

\author{
Martira Maddeppungeng*, Soedjatmiko** \\ * Divisi Tumbuh Kembang-Pediatri Sosial, Bagian Ilmu Kesehatan Anak FK UNHAS/RS DR Wahidin \\ Sudirohusodo Makasar \\ ** Divisi Tumbuh Kembang-Pediatri Sosial, Departemen Ilmu Kesehatan Anak FKUI, Jakarta
}

\begin{abstract}
Latar belakang. Kemampuan berbahasa merupakan indikator seluruh perkembang
Tujuan Penelitian. Mendapatkan gambaran umum pada anak dengan keterlambatan bicara/bahasa dengan menggunakan ELM scale 2.

Metode. Penelitian deskriptif potong lintang dilakukan pada 49 anak berusia 1-36 bulan dengan keterlambatan bicara di Poliklinik Tumbuh Kembang RSUP Cipto Mangunkusumo (RSCM) dan RSIA Hermina Bekasi, pada bulan September sampai Desember 2006.

Hasil. Persentase anak dengan gangguan bicara ekspresif 22 (44,9\%). Berdasarkan nilai persentil skor, terbanyak $30(61,2 \%)$ mempunyai nilai basal pada auditori ekspresif < 2, dan $19(38,8 \%)$ yang mempunyai nilai persentil skor 2-98. Walaupun nilai ini berada pada rentang skor 2-98, anak yang mempunyai persentil skor 2,5,10 tetap didapatkan fail menurut umur pada rentang 75-90\%( non critical item) penilaian ELM scale 2. Hal ini masih lebih baik dibanding jika anak mempunyai nilai skor standar <2 dengan keterlambatan jauh di bawah normal untuk umur yang sama.

Kesimpulan. Dengan penilaian ELM scale 2 pada anak keterlambatan bicara, dapat jelas terlihat keterlambatan terjadi pada sektor Auditori Ekspresi (AE), Auditori Reseptif (AR) atau Visual. Point skor yang rendah pada Auditori Reseptif merupakan petunjuk perlunya pemeriksaan pendengaran pada anak keterlambatan bicara (Sari Pediatri 2007; 9(2):93-100).
\end{abstract}

Kata kunci: keterlambatan bicara, ELM scale 2

\footnotetext{
Alamat korespondensi

dr Martira Maddeppungeng SpA.

Divisi Tumbuh Kembang-Pediatri Sosial, Bagian Ilmu Kesehatan Anak FK UNHAS/RS DR Wahidin Sudirohusodo JL Perintis Kemerdekan Km 11 Makassar 90245.

Telpon (0411) 584461 Fax (0411) 584461. Email : bikafkuh@yahoo.com
}

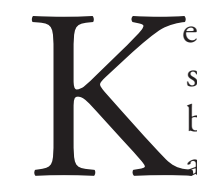

emampuan berbahasa merupakan indikator seluruh perkembangan anak. Kemampuan berbahasa sensitif terhadap keterlambatan atau kerusakan pada sistem lainnya, sebab melibatkan kemampuan kognitif, sensori motor, psikologik, emosi, dan lingkungan sekitar anak. Seorang 
anak tak akan mampu berbicara tanpa dukungan dari lingkungannya. Mereka harus mendengar pembicaraan yang berkaitan dengan kehidupannya sehari-hari maupun pengetahuan tentang dunia. Mereka harus belajar mengekspresikan dirinya, membagi pengalamannya dengan orang lain dan mengemukakan keinginannya. ${ }^{1}$

Keterlambatan bicara dapat menimbulkan dampak di bidang sosial, personal dan akademik. Identifikasi dini dan intervensi yang tepat akan mengurangi defisit emosional, sosial, dan kognitif yang timbul dan memperbaiki prognosis. ${ }^{2,6-8}$ Beberapa instrumen dapat digunakan untuk skrining perkembangan bicara yaitu Mac Arthur Communicative Development Inventory, Denver II, Early Languge Milestone scale 2 (ELM scale 2), Clinical Linguistic and Auditory Milestone Scale (CLAM scale) dan Sentence Repetition Screening Test. ${ }^{2-7}$

Penilaian ELM scale 2 adalah penilaian sederhana yang dapat digunakan untuk menilai perkembangan bahasa pada anak umur di bawah 3 tahun dan tes difokuskan pada bahasa ekspresif, reseptif dan visual. Tes ini mudah dilakukan dan hanya membutuhkan waktu beberapa menit untuk pemeriksaan. ${ }^{2,6,7}$ Dari hasil ELM scale 2 dapat dinilai dengan metode lulus/ gagal dan metode point skoring. Metode point skoring menunjukkan ranking, skor standar, usia ekuivalen untuk setiap aspek dan skor bahasa secara umum. ${ }^{7}$ Coplan (1982) pada penelitian anak risiko tinggi dengan ELM scale 2 metode lulus / gagal mendapatkan sensitivitas 97\%, dan spesifitas $93 \%$. $^{7}$

Penggunaan ELM scale 2 sebagai skrining untuk mendeteksi keterlambatan bicara bahasa belum lazim digunakan dalam praktek khususnya di klinik tumbuh kembang. Tujuan penelitian ini adalah untuk mendapatkan gambaran umum pada anak dengan keterlambatan bicara/bahasa dengan menggunakan ELM scale 2.

\section{Metode}

Penelitian ini merupakan penelitian deskriptif dengan desain studi potong lintang. Populasi target adalah anak dengan keterlambatan bicara dan bahasa. Populasi terjangkau adalah anak berusia 1-36 bulan dengan keterlambatan bicara dan bahasa di poliklinik Tumbuh Kembang RSCM dan RSIA Hermina Bekasi selama bulan September - 1 Desember 2006. Kriteria penolakan jika anak, orangtua dan atau pengasuh tidak kooperatif atau tidak menyelesaikan seluruh rangkaian pemeriksaan.
Dilakukan pencatatan data dasar pasien yang meliputi nama, usia, tanggal lahir, jenis kelamin, dan alamat serta melakukan pemeriksaan fisis pada semua pasien yang memenuhi kriteria inklusi. Pertama dilakukan uji tapis Denver II yang dilanjutkan dengan uji tapis ELM scale 2.

Anak dikatakan gangguan bicara apabila dengan pemeriksaan Denver II didapatkan adanya keterlambatan bicara pada sektor bahasa dan dengan metode lulus/gagal pada ELM scale 2 didapatkan gagal satu atau lebih pada sektor auditori ekspresif (AE), auditori reseptif (AR) dan visual. Penilaian perkembangan bahasa dinilai berdasarkan ELM scale 2 dengan penggunaan sistem point-scoring. Skor numerik atau skor baris ditentukan untuk setiap aspek. Skor bahasa secara umum dihitung dari jumlah total tiga aspek. Skor baris kemudian dikonversikan menjadi nilai skor persentil untuk umur, skor standar ekuivalen dan usia kronologis ekuivalen dengan menggunakan lampiran 1-6.

Dalam proses skoring harus ada pemeriksa dan historian (orang yang paling mengetahui kondisi anak). Pengisian dimulai dengan menarik garis vertikal pada formulir penilaian sesuai umur anak. Usia anak dinyatakan dalam bulan berdasarkan DOT (Date of testing) dan DOB (date of birth). Skala usia 1-12 bulan dinyatakan dalam 1 unit pada aksis horisontal yang sesuai dengan 1 bulan, sedangkan di atas 1 tahun 1 unit sesuai dengan 2 bulan. Setiap butir yang akan diuji pada formulir scoring dinyatakan dalam bentuk diagram batang horisontal. Batang putih menunjukkan usia tahapan perkembangan bahasa yang dapat dicapai oleh $25-50 \%$ anak populasi umum, abu-abu 50\%-75\% dan batang hitam 75$90 \%$. Kegagalan pada batang sampai $90 \%$ disebut noncritical items sedangkan lebih dari $90 \%$ disebut critical item. Setiap butir diawali dengan huruf yang menunjukkan cara yang diperbolehkan untuk melakukan uji pada butir tersebut yaitu huruf $\mathrm{H}$ (history), T (testing), O (observation). Setiap butir dinyatakan lulus jika anak lulus melalui cara yang diperbolehkan pada butir tersebut. ${ }^{7}$

Subjek mendapat skor 1 untuk setiap butir atau skor 1 untuk setiap bagian dari butir yang memiliki beberapa bagian. Skor numerik atau skor baris ditentukan untuk setiap aspek. Skor bahasa secara umum (global language score) dihitung dari jumlah total tiga aspek. Sebagian besar pada ELM scale 2 terdiri dari satu respon sehingga memiliki skor 1 jika butir tersebut lulus. Namun terdapat lima butir yang 
memiliki beberapa bagian yaitu: Butir AE 18 (8 point), AR10 (3 point), AR11 (3 point), AR12 (4 point), AR13 (4 point). Skor baris ini kemudian akan dikonversikan menjadi nilai persentil skor untuk umur, skor standar ekuivalen dan usia kronologis ekuivalen (usia kronologis pada skor numerik yang menunjukkan nilai median atau persentil 50) ${ }^{7}$

Tabel 1. Karakteristik subjek penelitian

\begin{tabular}{|c|c|c|}
\hline $\begin{array}{c}\text { Karakteristik subjek } \\
\text { penelitian }\end{array}$ & $\mathrm{n}$ & $\%$ \\
\hline \multicolumn{3}{|l|}{ 1. Usia (bulan) } \\
\hline $0-12$ & 6 & 12.2 \\
\hline$>12-24$ & 24 & 49,0 \\
\hline$>24-36$ & 19 & 38,8 \\
\hline \multicolumn{3}{|l|}{ 2. Jenis kelamin } \\
\hline Laki & 31 & 63,0 \\
\hline Perempuan & 18 & 36,7 \\
\hline \multicolumn{3}{|l|}{ 3. Status gizi* } \\
\hline Obesitas & 3 & 6,1 \\
\hline Overweight & 2 & 4,1 \\
\hline Cukup & 25 & 51,0 \\
\hline Kurang & 19 & 38,8 \\
\hline \multicolumn{3}{|l|}{ 4. Lingkar kepala $(\mathrm{cm})$} \\
\hline Normal & 34 & 69,4 \\
\hline Mikrosepal & 15 & 30,6 \\
\hline \multicolumn{3}{|l|}{ 5. Berat badan lahir (gram) } \\
\hline $2500-4000$ & 46 & 93,3 \\
\hline$<2500$ & 3 & 6,1 \\
\hline \multicolumn{3}{|l|}{ 6. Persalinan } \\
\hline Seksio & 16 & 32,7 \\
\hline Spontan & 33 & 67,3 \\
\hline \multicolumn{3}{|l|}{ 7. Faktor risiko } \\
\hline Ada & 25 & 51,0 \\
\hline Tak ada & 24 & 49,0 \\
\hline \multicolumn{3}{|l|}{ 8. Riwayat keluarga } \\
\hline Ada & 13 & 26,5 \\
\hline Tak ada & 36 & 73,5 \\
\hline \multicolumn{3}{|l|}{ 9. Pendidikan } \\
\hline Ayah - S1 & 25 & 51,0 \\
\hline - SMA/D3 & 17 & 34,7 \\
\hline - SMP & 7 & 14,3 \\
\hline Ibu - S1 & 19 & 38,8 \\
\hline - SMA/D3 & 22 & 44,9 \\
\hline - SMP & 8 & 16,3 \\
\hline
\end{tabular}

*Status gizi obesitas (>120\%), lebih (110-120\%), gizi cukup (90$110 \%)$, gizi kurang(70-90\%), gizi buruk (<70\%) menurut klasifikasi Waterlow tahun 1972

\section{Hasil}

Dari 51 anak usia 1-36 bulan yang masuk dalam penelitian terdapat dua subjek yang dikeluarkan dari penelitian. Satu subjek dikeluarkan karena data auditori reseptif tidak dapat dinilai, satu lainnya karena setelah dinilai global age berada di atas 36 bulan, dengan demikian data yang diolah adalah 49 subjek.

Dari Tabel 1 tampak kelompok umur 12-24 bulan merupakan kelompok terbanyak, yakni 49,9\% dengan laki-laki 31(63\%). Terdapat 15 (30,6\%) anak dengan ukuran lingkar kepala masuk kategori mikrosefal dan 25 (51\%) anak mempunyai faktor risiko.

Dari Tabel 2 berdasarkan prosentase penyakit dengan keterlambatan bicara/bahasa didapatkan terbanyak delay speech ekspresif 14 (28,6\%) dan delay speech ekspresif dengan keterlambatan motorik kasar $8(16,3 \%)$, palsi serebral $8(16,3 \%)$.

Berdasarkan skor persentil (Tabel 3) dari 49 anak dengan keterlambatan bicara/bahasa yang mempunyai nilai berada pada persentil $<2$ yaitu pada auditori ekspresif 30 (61,2\%), auditori ekspresif 17 (34\%), dan visual $13(26,5 \%)$.

Nilai skor standar ekuivalen pada (Tabel 4) dengan nilai $<69$ yaitu auditori ekspresif 30 $(61,2 \%)$, auditori reseptif $17(34,7 \%)$, dan visual $13(26,5 \%)$

Tabel 2. Persentase penyakit dengan keterlambatan bicara/ bahasa

\begin{tabular}{lcc}
\hline \multicolumn{1}{c}{ Penyakit } & Jumlah & $\%$ \\
\hline I. Delay speech ekspresif tanpa penyerta & 14 & 28,6 \\
II. Delay speechs dengan penyakit penyerta & & \\
- ADD/ADHD* & 4 & 8,2 \\
- ASD88 & 2 & 4.1 \\
- Palsi serebral & 8 & 16,3 \\
- Delay speech + motorik kasar & 8 & 16,3 \\
- Sindrom Down & 4 & 8,2 \\
- Global delay & 3 & 6,1 \\
- Hearing Loss & 3 & 6,1 \\
- Hipotiroid kongenital & 1 & 2,0 \\
- Spasme infantil & 2 & 4,1 \\
\hline Total & 49 & 100 \\
\hline
\end{tabular}

*ADD/ADHD : Attention Defisit Disorder/,Attention Defisit Hyperactivity Disorder, ${ }^{88} A S D$ : Autistic Spectrum Disorders 
Martira Maddeppungeng dkk: Penilaian Early Language Milestone Scale 2 (Elm Scale 2) pada Anak dengan Keterlambatan Bicara

Tabel 3. Skor persentil pada ELM Scale 2

\begin{tabular}{ccccc}
\hline $\begin{array}{c}\text { Skor standar } \\
\text { persentil }\end{array}$ & $\begin{array}{c}\text { Global } \\
\text { language (\%) }\end{array}$ & $\begin{array}{c}\text { Auditori } \\
\text { ekspresif (\%) }\end{array}$ & $\begin{array}{c}\text { Auditori } \\
\text { reseptif (\%) }\end{array}$ & $\begin{array}{c}\text { Visual } \\
(\%)\end{array}$ \\
\hline $\begin{array}{c}69-131 \\
<69\end{array}$ & $15(30,6)$ & $19(38,8)$ & $32(65,3)$ & $36(73,5)$ \\
\hline
\end{tabular}

Tabel 4. Skor standar ekivalen ELM Scale 2

\begin{tabular}{ccccc}
\hline $\begin{array}{c}\text { Skor standar } \\
\text { ekuivalen }\end{array}$ & $\begin{array}{c}\text { Global } \\
\text { language (\%) }\end{array}$ & $\begin{array}{c}\text { Auditori } \\
\text { ekspresif (\%) }\end{array}$ & $\begin{array}{c}\text { Auditori } \\
\text { reseptif (\%) }\end{array}$ & $\begin{array}{c}\text { Visual } \\
(\%)\end{array}$ \\
\hline $\begin{array}{c}69-131 \\
<69\end{array}$ & $15(30,6)$ & $19(38,8)$ & $32(65,3)$ & $36(73,5)$ \\
\hline
\end{tabular}

Tabel 5. Umur skor ELM scale 2

\begin{tabular}{cccc}
\hline $\begin{array}{c}\text { Umur } \\
\text { (bulan) }\end{array}$ & $\begin{array}{c}\text { Global } \\
\text { language(\%) }\end{array}$ & $\begin{array}{c}\text { Auditori } \\
\text { ekspresif (\%) }\end{array}$ & $\begin{array}{c}\text { Auditori } \\
\text { reseptif (\%) }\end{array}$ \\
\hline $0-12$ & $24(49,0)$ & $30(61,2)$ & $23(46,9)$ \\
$>12-24$ & $24(49,0)$ & $18(36,7)$ & $19(38,8)$ \\
$>24-36$ & $1(2,0)$ & $1(2,0)$ & $7(14,3)$ \\
\hline
\end{tabular}

Berdasarkan umur skor (Tabel 5) terbanyak kemampuan anak berada pada kelompok 0-12 bulan yaitu auditori ekspresif $30(61,2 \%)$, auditori reseptif 23 (46,9\%). Penilaian umur skor didapatkan pada kelompok 0-6 bulan yaitu10 (20,4\%) dan kelompok umur $>6-18$ bulan $39(79,9 \%)$.

\section{Diskusi}

Bahasa adalah semua upaya berkomunikasi, pikiran, ide dan perasaan disimbolisasikan untuk dapat memberi pengertian kepada orang lain..$^{1,3,9,10}$ Keberhasilan perkembangan bicara dan bahasa tergantung pada integrasi antara kognitif, auditori dan sistem motor. ${ }^{3,6,11}$ Bahasa dapat dibedakan atas bahasa reseptif dan bahasa ekspresif. Bahasa reseptif mengacu pada kemampuan untuk mengerti bahasa orang lain meliputi kemampuan visual dan kemampuan auditori (mendengarkan). Bahasa ekspresif adalah kemampuan anak untuk mengungkapkan baik secara visual (tulisan, tanda) atau auditori (berbicara). ${ }^{1,5,9}$

Bicara adalah suatu bentuk bahasa ekspresif yang diucapkan yang berhubungan dengan aspek mekanis produksi suara. ${ }^{9,12,13}$ Berbicara merupakan hasil signal akustik dan merupakan interaksi fisiologik yang kompleks berkaitan dengan sistem pernafasan, laring dan struktur oral ${ }^{1,3,9,12}$ Secara umum dikatakan terlambat bicara jika perkembangan bicara anak secara signifikan di bawah standar untuk anak normal dengan usia yang sama. ${ }^{2,7}$ Menurut Aram (1987), ${ }^{5}$ gangguan bicara pada anak dapat disebabkan oleh kelainan/ faktor lingkungan sosial anak, masalah sistem masukan/input, sistem pusat bicara dan bahasa serta sistem produksi. Keterlambatan bicara dapat merupakan manifestasi klinis beberapa penyakit antara lain retardasi mental, gangguan pendengaran, maturation delay, gangguan bicara ekspresif, bilingual dan autisme. ${ }^{1,2,7,14}$

Pada penelitian ini, jumlah anak dengan keterlambatan bicara/bahasa didapatkan laki laki lebih banyak. Hal ini berbeda dengan yang dilaporkan oleh Leung yakni 3-4 kali lebih banyak ditemukan pada anak laki dari pada perempuan ${ }^{2,7} \mathrm{Hal}$ ini mungkin karena jumlah sampel penelitian ini kurang sehingga didapatkan hasil yang berbeda.

Anak dengan riwayat ibu sakit selama kehamilan, trauma perinatal, infeksi asfiksia, pertumbuhan terhambat, penggunaan obat ototoksik riwayat psikososial secara signifikan akan mengalami keterlambatan bicara/bahasa, ${ }^{1,2,7}$ Keterlambatan bahasa di antara 49 anak dengan keterlambatan perkembangan bicara/bahasa terdapat 25 (51\%) anak yang mempunyai (faktor risiko). Faktor risiko biomedik maupun risiko lingkungan psikososial, atau sosial ekonomi yang dialami sejak masa konsepsi sampai masa neonatal, secara langsung maupun tak langsung dapat mengganggu perkembangan gerak, 
komunikasi, kognitif, emosi sosial dan perilaku. Semakin banyak faktor risiko, semakin banyak dan berat aspek perkembangan yang terganggu. Bentuk gangguan yang sering adalah palsi serebral, retardasi pertumbuhan, gangguan penglihatan ${ }^{20}$ Faktor-faktor risiko yang didapatkan dari penelitian ini antara lain: prematur, hiperbilirubinemia, kejang, morbili, rubella, pasca ensefalitis, penyakit kronik (kardimiopati dengan gagal tumbuh, anemia, PJB sianotik).

Didapatkan keterlambatan bicara ekspresif 14 $(28,6 \%)$, keterlambatan bicara ekspresif dengan keterlambatan gerak kasar $8(16,3 \%)$ serta palsi serebral $8(16,3 \%)$, ADHD 4(8,2\%), sindrom Down 4(8,2\%), global delay $3(6,1 \%)$, hearing loss $3(6,1 \%)$ spasme infantil 2(4,1\%) hipotiroidisme kogenital 1(2,0\%). Keterlambatan bicara/bahasa dapat dijumpai pada keadaan seperti retardasi mental, hearing loss, Developmental Language Disordrer( DLD), autisme, bilingual, deprivasi psikososial dan palsi serebral ${ }^{1,2,6}$ serta keterlambatan berjalan. ${ }^{21}$ Menurut Leung gambaran diagnosis perkembangan pada anak pra sekolah dengan gangguan bicara didapatkan DLD (56\%), learning disability (26\%), retardasi mental (24\%), hearing loss $(9 \%)$, autisme (5\%), kejang (4\%). ${ }^{2}$ Global delay pada penelitian ini didapatkan adanya keterlambatan dari 4 sektor perkembangan pada tiga anak dengan penyakit kronik yakni PJB sianotik, kardiomopati dengan gagal tumbuh dan anemia kronik.

Penilaian ELM scale 2 dapat terjadi keterlambatan pada auditori ekspresif saja, atau keterlambatan auditori ekspresif bersama auditori reseptif. Pada penelitian ini terlihat persentase anak dengan gangguan bicara ekspresif 22 (44,9\%). Berdasarkan nilai persentil skor, terbanyak $30(61,2 \%)$ yang mempunyai nilai basal pada auditori ekspresif <2, dan $19(38,8 \%)$ yang mempunyai nilai persentil skor 2-98. Pada nilai ini walaupun berada pada rentang skor 2-98, anak yang mempunyai persentil skor 2,5,10 tetap didapatkan fail menurut umur pada rentang $75-90 \%$ ( non critical item) penilaian ELM scale 2. Hal ini masih lebih baik dibanding jika anak mempunyai nilai skor standar $<2$ dengan keterlambatan jauh di bawah umur normal untuk umur yang sama.

Standar skor ekuivalen, didapatkan gambaran sama dengan persentil skor yakni $30(61,2 \%)$ yang mempunyai nilai basal pada auditori ekspresif dengan standar skor ekuivalen $<69$, dan $19(38,8 \%)$ yang mempunyai nilai standar skor ekuivalen 62-131. Pada auditori reseptif dengan nilai persentil terlihat ada 17 (34\%) anak yang mempunyai nilai persentil $<2$ dan terbanyak $32(65,3 \%)$ berada pada persentil 2-98.

Terdapat tiga anak dengan dengan nilai persentil $<2$ mempunyai nilai point skor di auditori reseptif nol menunjukkan bahwa gagal sama sekali pada auditori reseptifnya. Adanya gangguan pendengaran bilateral pada anak (terutama derajat sedang $\&$ berat) yang terjadi di dalam masa perkembangan bicara akan mengakibatkan gangguan bicara. ${ }^{22}$ Apabila kedua telinga tak dapat mendengar kata yang diucapkan menunjukkan taraf ketulian tuli sangat berat bilateral dengan kesetaraan audimetrik $>81 \mathrm{~dB} .{ }^{16}$ Pasien ini didiagnosis sebagai profound hearing loss $(90 \mathrm{~dB})$. Penilaian ELM scale 2 dapat dinilai bahwa pada anak tersebut ada kehilangan pendengaran yang berat. Pemeriksaan pada auditori reseptif berupa penggunaan suara kira-kira setara 10-20 dB, dan icik-icik kira-kira 30-40 dB, sehingga bila anak dengan nilai point pada auditori reseptif pass (lulus) dapat dikatakan bahwa kecil kemungkinan ada kehilangan pendengaran. Dalam memeriksa sensitivitas pendengaran dengan menggunakan sumber bunyi tanpa kalibrasi sumber bunyi (suara, icik-icik) harus diperhatikan konsistensi intensitas dan jarak antara sumber bunyi dengan telinga pemeriksa serta spektrum frekuensi bunyi sebaiknya alat atau permainan penghasil bunyi frekuensi tinggi. ${ }^{17}$ Penilaian anak dengan keterlambatan bicara/bahasa membutuhkan gambaran-gambaran kualitatif seperti integlibility, pragmatik, prosodi, kelancaran dan suara dan gambaran kuantitatif seperti banyak kata, konstruksi tata bahasa, pendengaran yang komprehensif dan ketrampilan visual. ${ }^{2,6}$

Penyebab kelainan berbahasa bermacam-macam yang melibatkan berbagai faktor yang dapat saling berpengaruh antara lain kemampuan lingkungan, pendengaran, kognitif, fungsi saraf, emosi psikologis dan lain sebagainya. ${ }^{3,9,15,21}$ Anak dengan kesulitan pada auditori persepsi sehingga kesulitan memahami bentuk suara ke dalam kata-kata dan tak mengerti struktur kalimat. ${ }^{23}$ Kesulitan pada auditori persepsi/ reseptif dapat menunjukkan adanya keterlibatan pendengaran, kognitif, fungsi saraf (input dan proses di otak). Anak dengan defisit bahasa ekspresif harus dievaluasi adanya keterlambatan perkembangan, kehilangan pendengaran, gangguan emosi dan autisme. ${ }^{23}$ Kesulitan pada auditori ekspresi menunjukkan keterlibatan pada kognitif dan oro-motor (proses di otak dan out put). 
Tabel 6. Gambaran umur kronologis dibandingkan umur kemampuan basal

\begin{tabular}{cccc}
\hline $\begin{array}{c}\text { Umur } \\
\text { (bulan) }\end{array}$ & $\begin{array}{c}\text { Sampel } \\
\mathrm{n}(\%)\end{array}$ & $\begin{array}{c}\text { Auditori } \\
\text { ekspresif } \mathrm{n}(\%)\end{array}$ & $\begin{array}{c}\text { Auditori } \\
\text { reseptif } \mathrm{n}(\%)\end{array}$ \\
\hline $0-12$ & $6(12,2)$ & $30(61,2)$ & $23(46,9)$ \\
$>12-24$ & $24(49,0)$ & $18(36,7)$ & $19(38,8)$ \\
$>24-36$ & $19(38,8)$ & $1(2,0)$ & $7(14,3)$ \\
\hline
\end{tabular}

Pada penelitian ini terbanyak kelompok umur $>12-24$ bulan 24 responden $(49,0 \%)$ dan $>24-36$ bulan 19 responden $(38,8 \%)$. Dengan penilaian ELM scale 2 berdasarkan umur ekuivalen terlihat kemampuan auditori ekspresif anak terbanyak kemampuannya masuk pada kelompok umur 0-12 bulan yakni AE 61,2\% dan AR 46,9\%. Temuan ini menunjukkan kemampuan basal anak tak sesuai dengan umur anak atau dengan nilai persentil skor $<2$ (Tabel 6).

Anak normal yang berusia 18 bulan atau lebih seharusnya telah lulus butir aspek visual. Penilaian bahasa visual tetap dilakukan walaupun umur anak lebih dari 18 bulan pada anak dengan keterlambatan bicara/ bahasa. Dari penelitian ini didapatkan bahasa visual dengan nilai persentil skor <2 (skor ekuivalen<69) sebanyak 13 (26,5\%). Berdasarkan penilaian umur skor, kemampuan bahasa visual terbanyak kelompok umur $>6-18$ bulan yaitu $39(79,9 \%)$ dan kelompok umur 06 bulan $(20,4 \%)$ menunjukkan sebagian besar ada kesesuaian umur pada bahasa visual.

Keterbatasan pada penelitian ini, yaitu alat yang digunakan untuk menguji pendengaran misalnya icik-icik tidak dikalibrasi sehingga tidak diketahui derajat desibel $(\mathrm{dB})$ kemampuan pendengaran yang diperiksa.

Sebagai kesimpulan pada penilaian ELM scale 2 anak keterlambatan bicara dapat jelas terlihat keterlambatan anak pada sektor Auditori Ekspresi (AE), Auditori Reseptif (AR) atau Visual. Point skor yang rendah pada Auditori Reseptif merupakan petunjuk perlunya pemeriksaan pendengaran pada anak dengan keterlambatan bicara/bahasa. Pada anak dengan keterlambatan bicara/bahasa yang bermanifestasi klinik sebagai global delay atau gangguan kognitif dengan ELM scale 2 terlihat ada keterlambatan pada semua sektor. Untuk waktu yang akan datang, dapat disarankan pada penggunaan ELM scale 2 sebagai skrining sebaiknya menggunakan sumber bunyi yang terkalibrasi. Jika menggunakan sumber bunyi tanpa kalibrasi harus diperhatikan konsistensi intensitas dan jarak antara sumber bunyi dan jarak antara sumber bunyi dengan telinga terperiksa.

\section{Daftar Pustaka}

1. Soetjiningsih. Gangguan bicara dan bahasa pada anak. Dalam: Ranuh G,penyunting. Tumbuh kembang anak; Jakarta: EGC; 1995. h. 237-47.

2. Leung A, Kao CF. Evaluation and management of the child with speech delayed. Am Fam Phys 1999;59.1-11.

3. Feldman HM. Evaluation and management of language and speech disorders in preschool children. Pediatrics in review 2005; 26:131-40.

4. Needleman RD. Growth and Development. Dalam: Behrman RE, Kliegman RM, Jenson HB, penyunting. Nelson textbook of pediatrics, Edisi ke -17. Philadelphia: WB Saunders; 2004. h. 23-5.

5. Aram DA. Speech \& language. Dalam: Behrman RE, Kliegman RM, Jenson HB, penyunting. Nelson textbook of pediatrics. Edisi ke-17. Philadelphia: WB Saunders; 2004. h. 95-7.

6. Macias MM, Wegner ML. Speech and language development and disorder. Dalam: Maria BL, penyunting. Current management in child neurology. Edisi ke-3. London: BC Decker Inc; 2005. h. 225-30.

7. Coplan J. Early language milestone scale-2. Edisi ke-2. Texas: Prp-Ed; 1993

8. Goldson E, Hagerman RJ. Child development \& behavior. Dalam: Hay WW, Hayward AR, Levin MY, penyunting. Current pediatric diagnosis \& treatment. Edisi ke-15. New York: Mc Graw-Hill; 2001. h. 72-3.

9. Levine DA. Growth and developmental. Dalam: Behrman RE, Kliegman RM, Jenson HB, penyunting. Nelson essentials of pediatrics. Edisi ke-15. Philadelphia: Saunders; 2006.h.16-24.

10. Coplan J. Language delays. Dalam: Parker S, Zukckerman B, Augustyn M, penyunting. Developmental and behavioral pediatrics, a handbook for primary care. Edisi ke-2. Philadelphia: Lippincott Williams \& Wilkins; 2005. h.222-6.

11. Pangabean R. Neurologi gangguan bicara. Konferensi Nasional Autisme-1. Towards a better life for autistic individuals. Jakarta 2003.h.221-7.

12. Wolraich ML, Casey P, Felice ME, Jellinek MS. Developmental competency. Dalam: Wolraich ML 
penyunting. The classification of child and adolescent mental diagnosis in primary care.American Academy Pediatric: 1996.h.83-6.

13. Kelly DP, Sally JI. Disorders of speech and languge. Dalam: Levine MD, Carey WB, Crokcer AC, penyunting. Developmental-behavioral pediatris. Edisi ke-3. Philadelphia: WB Saunders; 1999.h.621-31

14 Grizzle KL,Simms MD. Early language development and language learning disabilities. Pediatrics in Review 2005;26:274-82.

15. Crosley CJ. Speech and lnguge disorders. Dalam: Swaiman KE, Ashwal S. penyunting, Pediatric neurology principles \& practice. Edisi ke-3. St Louis Baltimore: Mosby Inc; 1999.h.568-74.

16. Soetjiningsih. Penilaian perkembangan anak. Dalam: Ranuh G, penyunting. Tumbuh kembang anak; Jakarta: EGC; 1995. h. 63-7.

17. Grizzle KL, Simms MD. Early language development and language learning disabilities. Pediatrics in Review 2005;26:274-82.

18. Suwento R, Hendarmin H. Deteksi dini gangguan pendengaran pda nak untuk optimalisasi perkembangan kecerdasan. Dalam: Sularyo TS, Musa DA, Gunardi H, penyunting. Deteksi dan intervensi dini penyimpangan tumbuh kembang anak dalam upaya optimalisasi kualitas sumber daya manusia. Pendidikan Kedokteran Berkelanjutan Ilmu Kesehatan
Anak XXXVII. Jakarta: Balai Penerbit FKUI; 1996. h.189-95.

19. Kusumuputro S. Perkembangan fungsi luhur. Dalam: Sularyo TS, Musa DA, Gunardi H,penyunting. Deteksi dan intervensi dini penyimpangan tumbuh kembang anak dalam upaya optimalisasi kualitas sumber daya manusia. Pendidikan Kedokteran Berkelanjutan Ilmu Kesehatan Anak XXXVII. Jakarta: Balai Penerbit FKUI; 1996. h. 23-31.

20. Hardi JC, Tombin JB. Disorders of speech and language developmental. Dalam: Wolraich ML, penyunting. Disorders of development and learning, a practical guide to assessment and management. Edisi ke-2. St.Louis: Mosby-Year Book; 1996. h. 262-96.

21. Soedjatmiko. Stimulasi dini untuk bayi dan anak. Dalam: Pulungan AB, Hendarto A, Hegar B, Oswari $\mathrm{H}$, penyunting. Nutrition growth development. Jakarta: IDAI Jaya; 2006. h. 27-46.

22. Pollak M.Language development. Textbook development pediatrics. London: Churcill Livingstone; 1993. h. 275-90.

23. Suwento R. Anak belum dapat berbicara, apakah dikarenakan tuli?.Medicinal 2003; 4:2

24. Levine MD.The elements of developmental function Dalam: Behrman RE, Kliegman RM, Jenson HB, penyunting. Nelson textbook of pediatrics. Edisi ke -13 . Philadelphia: WB Saunders; 1987. h. 87-9. 